\title{
Decomposition of carbon adsorbed on iron (III)-treated clays and their effect on the stability of soil organic carbon and external carbon inputs
}

\author{
Mengyang You $\cdot$ Xia Zhu-Barker (D) Timothy A. Doane $\cdot$ William R. Horwath
}

Received: 4 March 2021 / Accepted: 28 October 2021 / Published online: 19 November 2021

(C) The Author(s) 2021

\begin{abstract}
The interaction of organic carbon (OC) with clay and metals stabilizes soil carbon $(\mathrm{C})$, but the influence of specific clay-metal-OC assemblages (flocs) needs further evaluation. This study aimed to investigate the stability of flocs in soil as affected by external $\mathrm{C}$ inputs. Flocs representing OC-mineral soil fractions were synthesized using dissolved organic $\mathrm{C}$ (DOC) combined with kaolinite (1:1 layer structure) or montmorillonite (2:1 layer structure) clays in the absence or presence of two levels of Fe (III) (named low or high $\mathrm{Fe}$ ). Flocs were mixed with soil (classified as Luvisol) and incubated with or without ${ }^{13} \mathrm{C}$ labelled plant residue (i.e., ryegrass) for 30 days. The $\mathrm{CO}_{2}$ emissions and DOC concentrations as well as their ${ }^{13} \mathrm{C}$
\end{abstract}

Responsible Editor: Karsten Kalbitz.

M. You

Key Laboratory of Mollisol Agroecology, Northeast Institute of Geography and Agroecology, Chinese Academy of Sciences, 138 Haping Rd, Harbin 150081, People's Republic of China

M. You $\cdot$ X. Zhu-Barker $(\bowtie)$.

T. A. Doane - W. R. Horwath

Biogeochemistry and Nutrient Cycling Laboratory, Department of Land, Air and Water Resources, University of California Davis, Davis, CA 95616, USA

e-mail:wyjzhu@ucdavis.edu; zhubarker@wisc.edu

X. Zhu-Barker

Department of Soil Science, University of Wisconsin-

Madison, Madison, Wisconsin 53709, USA signatures from all treatments were examined. Total C mineralization from flocs was approximately $70 \%$ lower than non-flocced DOC. The flocs made with montmorillonite had $16-43 \%$ lower $\mathrm{C}$ mineralization rate than those made with kaolinite with no $\mathrm{Fe}$ or low $\mathrm{Fe}$. However, when flocs were made with high Fe, clay mineralogy did not significantly affect total $\mathrm{C}$ mineralization. A positive priming effect (PE) of flocs on native soil OC was observed in all treatments, with a stronger PE found in lower Fe treatments. The high-Fe clay flocs inhibited ryegrass decomposition, while the flocs made without clay had no impact on it. Interestingly, flocs significantly decreased the PE of ryegrass on native soil $\mathrm{OC}$ decomposition. These results indicate that the adsorption of DOC onto clay minerals in the presence of $\mathrm{Fe}$ (III) stabilizes it against decomposition processes and its stability increases as $\mathrm{Fe}$ in flocs increases. Flocs also protect soil OC from the PE of external degradable plant $\mathrm{C}$ input. This study showed that Fe level and clay mineralogy play an important role in controlling soil C stability.

Keywords Carbon mineralization - Iron · Floc · Priming effect · Clay mineralogy 


\section{Introduction}

The adsorption of organic carbon (OC) onto mineral surfaces is an important mechanism of stabilizing soil organic carbon (SOC) (Kahle et al. 2002; Mikutta et al. 2007; von Luetzow et al. 2006; Han et al. 2016; Rasumssen et al. 2018). Phyllosilicate clays and iron minerals have long been recognized as reactive surfaces that adsorb OC (Balcke et al. 2002; Mikutta et al 2006; Kaiser and Guggenberger 2007). The OC stabilization effect in the absence of metals depends on particle size and surface charge (Eusterhues et al. 2005; Feng et al. 2005; Zhang et al. 2012). For example, kaolinitic clays with a 1:1 layer structure occur as larger particles but carry less charge compared to 2:1 clays (Greenland 1971), though the mineral size of kaolinites in soils varies (Singh and Gilkes 1992; West et al. 2004; Prandel et al. 2017). Six et al. (2002) found that soil dominated by 1:1 clays exhibited a lower $C$ sequestration potential compared to soil dominated by 2:1 clay minerals. The stability of OC on clay often occurs with hydrous Fe oxides, a common bridging metal (Saidy et al. 2012). The stability of organo-mineral associations (referred to as flocs) differs with clay type, and undoubtedly affects the priming effect (PE) outcomes in the presence of degradable $\mathrm{C}$ inputs.

Many studies have investigated the role of phyllosilicate clay minerals in stabilizing dissolved organic carbon (DOC) through adsorption interactions (Kahle et al. 2004; Saidy et al. 2012, 2013; Sodano et al. 2016). DOC is a mobile and reactive OC pool in soil that can adsorb and desorb from metal-clay assemblages (Wang et al. 2003). By measuring C mineralization following adsorption, these studies found that different clay minerals imparted various degrees of stability to OC. Moreover, Saidy et al. (2015) showed that plant $C$ adsorbed to pure phyllosilicate clays had a significant lower $\mathrm{C}$ mineralization rate compared to the absence of clay. Characteristics of clay minerals such as specific surface area (SSA) and cation exchange capacity (CEC) determine the degree to which DOC is adsorbed (Kahle et al. 2004). For example, coating of kaolinite with hydrous Fe oxide enhanced DOC sorption, but this phenomenon was not observed with montmorillonite due to its relatively limited available surface after coating of Fe (Saidy et al. 2012).
Co-precipitation of DOC and Fe commonly occurs in soils, sediments, and surface and ground water. It is believed that these floc formations are stable and have limited mobility following formation (Larsen 2009). The stability of flocs is in part promoted by the adsorbed OC's ability to protect $\mathrm{Fe}$ oxides from reduction to Fe (II) (Henneberry et al. 2012). Eusterhues et al. (2008) mentioned the important role of floc in immobilizing DOC and protecting it from microbial degradation. Studies in paddy soil and aquatic environments (Sodano et al. 2016) have shown that the rate of floc $\mathrm{C}$ decomposition was faster in wet than in dry seasons. The stability of OC in hydromorphic soils, such as rice paddies and wetlands, can be strongly controlled by its adsorption onto $\mathrm{Fe}$ (hydr)oxide (Henneberry et al. 2012; Sodano et al. 2016). These studies shed light on $\mathrm{C}$ associated with clays and $\mathrm{Fe}$ but do not provide insight into the $\mathrm{PE}$ that they potentially exert on other soil C pools, such as litter or other labile sources of $\mathrm{C}$.

The objectives of this study were to understand the decomposition of flocced OC formed through the interaction between DOC and clay sized minerals (i.e., phytosilicates with and without the presence of $\mathrm{Fe}$ species), and the effect of these minerals on the stability of other SOC pools as well as the decomposition of degradable $\mathrm{C}$ in plant residues. We hypothesized that (1) the decomposition rate of $\mathrm{C}$ in clay-FeOC flocs would decrease as $\mathrm{Fe}$ content in the flocs increased, (2) OC in kaolinite flocs would decompose faster than in montmorillonite flocs, and (3) the flocs made with low $\mathrm{Fe}$ and kaolinite would stimulate SOC and plant residue decomposition. To test these hypotheses, we conducted a laboratory incubation experiment using flocs made with kaolinite or montmorillonite clays precipitated with DOC in the absence or presence of different levels of Fe. Our results provide information on the role that Fe plays in stabilizing $\mathrm{OC}$ on clay surfaces as a function of clay mineralogy and how SOC and the degradable plant C substrate can be affected by flocs containing different Fe contents. 


\section{Materials and methods}

\section{Sample preparation}

\section{Extraction of dissolved organic carbon}

The DOC used to prepare floc products was extracted from mature corn residue (leaves and stems) (Zea mays L.). Before extraction, the corn residue (approximately $2 \mathrm{~cm}$ pieces) was inoculated with $2 \%$ soil solution (soil: water $=1: 50$ ) and pre-incubated at $40{ }^{\circ} \mathrm{C}$ for 30 days. The soil used for extracting soil solution was a silty clay loam (classified as Luvisol according to World Reference Base for Soil Resources) and collected from the Russell Ranch Sustainable Agricultural Facility, University of California-Davis, California. The purpose of this preincubation was to allow soil microorganisms to consume labile $\mathrm{C}$ in the residue to better reflect characteristics of soil DOC (Bertrand et al. 2006). After the pre-incubation, the residue ( $2 \mathrm{~kg}$ dry mass equivalent) was suspended in deionized water $(8 \mathrm{~L})$. The suspension was shaken at $170 \mathrm{r} \mathrm{min}^{-1}$ for $48 \mathrm{~h}$, left to settle for $48 \mathrm{~h}$, and filtered through a $0.45 \mu \mathrm{m}$ glass fiber filter. The DOC concentration in the filtrate was $1.6 \mathrm{~g} \mathrm{C} \mathrm{L} \mathrm{L}^{-1}$, determined by UV-persulfate digestion (Teledyne-Tekmar Phoenix 8000). The $\delta$ ${ }^{13} \mathrm{C}$ value of the DOC solution was $-15.8 \%$, determined by using a TOC analyzer (1010 OI Analytical, College Station, TX, USA) coupled to a PDZ Europa 20-20 isotope ratio mass spectrometer (Sercon Ltd., Cheshire, UK) at the Stable Isotope Facility, the University of California-Davis. Working DOC standards prepared with glucose of known mass and ${ }^{13} \mathrm{C}$ enrichment were used for quality control. Four analytical replicates of DOC solution were made and the standard deviation of the replicated ${ }^{13} \mathrm{C}$ analyses in this coupling system was $0.13 \%$.

\section{Preparation of iron-OC floc}

A flocculant solution $(1.75 \mathrm{M})$ was prepared consisting of $\mathrm{Fe}_{2}\left(\mathrm{SO}_{4}\right)_{3}$ powder in reagent grade $9 \mathrm{M} \mathrm{H}_{2} \mathrm{SO}_{4}$. The optimal dose of $\mathrm{Fe}_{2}\left(\mathrm{SO}_{4}\right)_{3}$ required to remove maximum DOC from the corn residue filtrate was determined in a parallel experiment by adding different amounts of $\mathrm{Fe}_{2}\left(\mathrm{SO}_{4}\right)_{3}$ into the filtrate solution until the concentration of the remaining DOC in the solution did not change anymore (Henneberry et al.
2012). Flocs were subsequently prepared using the optimal dose of coagulant and recovered by filtering the suspension through a $0.45 \mu \mathrm{m}$ glass fiber filter. The floc retained on the filter was oven-dried at $50{ }^{\circ} \mathrm{C}$.

\section{Preparation of clay-OC flocs}

Two clays were obtained from the Clay Minerals Society: kaolinite (low-defect kaolin, Warren Count, Georgia, USA; SSA: $10.0 \mathrm{~m}^{2} \mathrm{~g}^{-1}$ ) and Ca-rich montmorillonite (Gonzales County, Texas, USA; SSA: $\left.83.8 \mathrm{~m}^{2} \mathrm{~g}^{-1}\right)$. Clays adsorbed DOC from the filtrate solution (described above) by shaking $20 \mathrm{ml}$ DOC solution with $1 \mathrm{~g}$ clay for $12 \mathrm{~h}$ at $22{ }^{\circ} \mathrm{C}$. The $\mathrm{pH}$ of the mixtures was adjusted to 6.0 with $\mathrm{NaOH}$ before shaking (Saidy et al. 2013). The suspensions were then centrifuged and the pellets were washed with deionized water and centrifuged again; this step was repeated until no DOC was detected in the supernatant. The precipitates were oven-dried at $50{ }^{\circ} \mathrm{C}$ and then ground to pass $200 \mu \mathrm{m}$. The $\mathrm{C}$ concentration and $\delta^{13} \mathrm{C}$ value analyses of all the floc products were determined by using a VarioEL CHN combustion analyzer (Elementar Analysensysteme $\mathrm{GmbH}$, Hanau, Germany) interfaced to an isotope ratio mass spectrometer (PDZ Europa 20-20 IRMS, Sercon Ltd., Cheshire, U.K.). All the floc products had a similar $\delta$ ${ }^{13} \mathrm{C}$ value of $-15.8 \%$.

\section{Preparation of clay-iron-OC flocs}

The Fe (hydr)oxide-coated clays were prepared by suspending clay $(1 \mathrm{~g})$ in coagulant solution $(\mathrm{pH}=2.5$, $\mathrm{NaOH}$ adjusted) with different concentrations of $\mathrm{Fe}$ as $\mathrm{Fe}_{2}\left(\mathrm{SO}_{4}\right)_{3}: 20,40,80,120,160,200,240,280,320$, and $360 \mathrm{mg} \mathrm{Fe} \mathrm{L}^{-1}$. The minimum and maximum amounts of $\mathrm{Fe}$ coated with clays were chosen and named as "low $\mathrm{Fe}$ " and "high $\mathrm{Fe}$ ". The clay-Fe mixtures were shaken for $48 \mathrm{~h}$ at $22{ }^{\circ} \mathrm{C}$, and then centrifuged. This process was repeated numerous times until no $\mathrm{Fe}$ was detected in the supernatant using phenanthroline indicator (Saidy et al. 2012). The Fe-coated clays were then oven-dried at $50{ }^{\circ} \mathrm{C}$ and gently ground by mortar to pass a $200 \mu \mathrm{m}$ sieve. The $\mathrm{Fe}$ content of the Fe-coated clays was determined by suspending a known amount of the product in $1 \mathrm{M}$ $\mathrm{HCl}$, shaking for several hours to dissolve the iron species, and determination of dissolved iron. The "low $\mathrm{Fe}$ " products $\left(\mathrm{Fe}_{\text {low }}\right)$ contain $5.4 \mathrm{mg} \mathrm{Fe} \mathrm{g}^{-1}$ clay and 
$11.4 \mathrm{mg} \mathrm{Fe} \mathrm{g}^{-1}$ clay for kaolinite and montmorillonite, respectively. The "high $\mathrm{Fe}$ " products $\left(\mathrm{Fe}_{\text {high }}\right)$ contain $199.0 \mathrm{mg} \mathrm{Fe} \mathrm{g}^{-1}$ clay and $219.0 \mathrm{mg} \mathrm{Fe} \mathrm{g}^{-1}$ for kaolinite and montmorillonite, respectively. Clays with Fe coating were then used to adsorb DOC from the filtrate solution (described above) to form clayiron-OC flocs using the same procedure as described in "Preparation of clay-OC flocs".

Incubation experiment

\section{Soil incubation preparation}

The soil used for preparing the incubation medium was the same as that mentioned above for preparing the soil inoculum. The soil contained $19.39 \mathrm{~g} \mathrm{~kg}^{-1}$ OC, $2.58 \mathrm{~g} \mathrm{~kg}^{-1}$ total $\mathrm{N}$, and a $\delta{ }^{13} \mathrm{C}$ value of $26.7 \%$. The sand was washed with hydrochloric acid numerous times to remove nutrients and other ions. No $\mathrm{C}$ or $\mathrm{N}$ was detected in the washed sand. The washed sand was then mixed with soil at a ratio of 19: 1 (by mass) and air dried. Aliquots of the dried sand/soil (10 g dry mass) mix (hereafter referred to as soil medium) were placed into $60 \mathrm{ml}$ glass serum vials, wetted to $40 \%$ water holding capacity with deionized water, and pre-incubated at $22{ }^{\circ} \mathrm{C}$ in dark for 7 days.

\section{Experimental design}

After the pre-incubation, floc material or unflocced DOC was added to the soil medium at a rate of $0.2 \mathrm{mg}$ $\mathrm{C} \mathrm{g}^{-1}$ and mixed thoroughly with a glass rod. The soil medium alone (no floc or DOC additions) was treated as control. A separate set of treatments received enriched ${ }^{13} \mathrm{C}$-labled mature ryegrass residue (Lolium perenne L.) at a rate of $1 \mathrm{mg} \mathrm{C}$ per treatment (equals to $0.4 \mathrm{mg} \mathrm{C} \mathrm{g}^{-1}$ ) at the same time as floc addition. The ryegrass, with a $\delta{ }^{13} \mathrm{C}$ value of $538.0 \%$, was labeled by frequent ${ }^{13} \mathrm{CO}_{2}$ pulse labeling events according to Bird et al. (2003). The use of ${ }^{13} \mathrm{C}$-enriched ryegrass residue allowed us to sufficiently differentiate $\mathrm{C}$ mineralization from ryegrass vs. soil/floc mixtures to estimate the $\mathrm{PE}$ of ryegrass on soil/floc $\mathrm{C}$ and the effect of floc on ryegrass decomposition during incubation. For each treatment, a nutrient solution containing $\left(\mathrm{NH}_{4}\right)_{2} \mathrm{SO}_{4}$ and $\mathrm{K}_{2} \mathrm{HPO}_{4}$ was added to reach a final C: $\mathrm{N}$ and $\mathrm{C}$ : $\mathrm{P}$ of the soil/floc mixture of 10: 1 and 25: 1, respectively, to ensure no nutrient limitation. The moisture content of all the treatments was adjusted to $60 \%$ of water holding capacity with deionized water. Sample vials were closed with butyl rubber septa and crimp-sealed following the addition of nutrient solution and moisture adjustment. The headspace of sample vials was then immediately flushed with $\mathrm{CO}_{2}$-free air to ensure no background $\mathrm{CO}_{2}$ remained in the headspace. All the vials were incubated at $22{ }^{\circ} \mathrm{C}$ in the dark for 30 days. The experiment was set up as a completely randomized design with 18 treatments (summarized in Table 1), each with 4 replicates.

Gas sampling and analysis

Aliquots of $20 \mathrm{ml}$ gas samples were removed from the headspace of the vials on days $1,3,5,7,9,11,14,17$, 20, 23, 26, and 30 and transferred to evacuated exetainers (Labco, Ceredigion, United Kingdom). At each sampling event, all vials were flushed immediately after gas sampling with $\mathrm{CO}_{2}$-free air to ensure no $\mathrm{CO}_{2}$ remained in the headspace. The $\mathrm{CO}_{2}$ concentration in the gas samples was analyzed on a gas chromatograph with a thermal conductivity detector (Model 2014, Shimadzu Scientific Instruments). Stable $\mathrm{C}$ isotope analysis of $\mathrm{CO}_{2}$ in gas samples were analyzed on days $1,5,17$, and 30 on a Thermo GC combustion isotope ratio mass spectrometer (GC/CIRMS) consisting of a Trace GC Ultra gas chromatograph (Thermo Electron Corp., Milan, Italy) coupled to a Delta V Advantage IRAM through a GC/ C-III interface (Thermo Electron Corp., Bremen, Germany).

\section{Soil analysis}

At the end of the incubation, all treatments were extracted with $0.5 \mathrm{M} \mathrm{K}_{2} \mathrm{SO}_{4}$ (2:1 extractant volumeto-soil mass ratio). The extracts were filtered, and the supernatant analyzed for DOC concentration using UV-persulfate oxidation (Phoenix 8000, TeledyneTekmar) and ${ }^{13} \mathrm{C}$-DOC content using a TOC analyzer (1010 OI Analytical, College Station, TX, USA) coupled to a PDZ Europa 20-20 isotope ratio mass spectrometer (Sercon Ltd., Cheshire, UK) at the UC Davis Stable Isotope Facility. Working DOC standards prepared with glucose of known mass and ${ }^{13} \mathrm{C}$ enrichment were used for quality control. 
Table 1 Summary of the treatments

\begin{tabular}{ll}
\hline Treatment & Description \\
\hline Control & No floc or DOC solution was added into soil medium \\
DOC & Only DOC solution was added into soil medium \\
Fe-OC & The floc made with Fe and DOC was added into soil medium \\
M-OC & The floc made with montmorillonite and DOC was added into soil medium \\
Felow-M-OC & The floc made with low Fe-coated montmorillonite and DOC was added into soil medium \\
Fehigh-M-OC & The floc made with high Fe-treated montmorillonite and DOC was added into soil medium \\
K-OC & The floc made with kaolinite with adsorbed C was added into soil medium \\
Felow-K-OC & The floc made with low Fe-coated kaolinite and DOC was added into soil medium \\
Fehigh-K-OC & The floc made with high Fe-treated kaolinite and DOC was added into soil medium \\
\hline
\end{tabular}

Calculation

\section{Treatments without ryegrass addition}

The difference in $\delta{ }^{13} \mathrm{C}$ natural abundance of soil medium (-26.7\%o) and flocs $(-15.8 \%)$ was used to calculate the contribution of these $\mathrm{C}$ pools to $\mathrm{CO}_{2}$ production. The fraction of $\mathrm{CO}_{2}\left(f_{\text {floc }}\right)$ and $\mathrm{CO}_{2}$ production $\left(\mathrm{CO}_{2}\right.$, floc $)$ derived from flocs was calculated as follows:

$$
\begin{gathered}
f_{\text {floc }}=\left(\delta^{13} \mathrm{C}-\mathrm{CO}_{2, \text { treatment }}-\delta^{13} \mathrm{C}-\mathrm{CO}_{2 \text { control }}\right) \\
\quad /\left(\delta^{13} \mathrm{C}_{\text {floc }}-\delta^{13} \mathrm{C}_{\text {control }}\right) \\
\mathrm{CO}_{2, \text { floc }}=\mathrm{CO}_{2, \text { total }} \times f_{\text {floc }}
\end{gathered}
$$

where $\delta{ }^{13} \mathrm{C}-\mathrm{CO}_{2}$, treatment and $\delta{ }^{13} \mathrm{C}-\mathrm{CO}_{2}$, control are the $\delta{ }^{13} \mathrm{C}$ value of mixed $\mathrm{CO}_{2}$ produced from the treatments of soil medium amended with flocs and control (soil without floc), respectively. $\Delta{ }^{13} \mathrm{C}_{\text {floc }}$ and $\delta$ ${ }^{13} \mathrm{C}_{\text {control }}$ refer to the $\delta{ }^{13} \mathrm{C}$ signature of the flocs and soil medium in the control, respectively. $\mathrm{CO}_{2}$, total represents the total $\mathrm{CO}_{2}$ production in the floc treatments.

The $\mathrm{CO}_{2}$ production $\left(\mu \mathrm{g} \mathrm{g}^{-1}\right)$ derived from soil medium only was derived from native $\mathrm{SOC}\left(\mathrm{CO}_{2}\right.$, soc $)$ and was determined as follows:

$\mathrm{CO}_{2, \text { SOC }}=\mathrm{CO}_{2, \text { total }} \times\left(1-f_{\text {floc }}\right)$

The PE $\left(\mu \mathrm{g} \mathrm{g}^{-1}\right)$ of flocs on native SOC mineralization was defined as follows:

$\mathrm{PE}=\mathrm{CO}_{2, \mathrm{SOC}}-\mathrm{CO}_{2, \text { control }}$ where $\mathrm{CO}_{2}$, control was the $\mathrm{CO}_{2}$ production from the treatment of soil medium alone (control, no floc and DOC addition).

In the DOC-only treatment, the fraction of $\mathrm{CO}_{2}$ $\left(f_{\mathrm{DOC}}\right)$ and $\mathrm{CO}_{2}$ production $\left(\mathrm{CO}_{2}\right.$, DOC $)$ derived from DOC was calculated using the same approach as described above by replacing floc pool with DOC pool in the calculation.

Treatments with and without ryegrass straw addition

The fraction of $\mathrm{CO}_{2}$ derived from ryegrass straw was calculated as follows:

$$
\begin{aligned}
f_{\text {straw }}= & \left(\delta^{13} \mathrm{C}-\mathrm{CO}_{2, \text { withstraw }}-\delta^{13} \mathrm{C}\right. \\
& \left.-\mathrm{CO}_{2, \text { withoutstraw }}\right) /\left(\delta^{13} \mathrm{C}_{\text {straw }}-\delta^{13} \mathrm{C}_{\text {withoutstraw }}\right)
\end{aligned}
$$

where $\delta{ }^{13} \mathrm{C}-\mathrm{O}_{2}$, with straw and $\delta{ }^{13} \mathrm{C}-\mathrm{CO}_{2}$, without straw are the $\delta{ }^{13} \mathrm{C}$ value of mixed $\mathrm{CO}_{2}$ produced from the treatments with and without straw for each floc, respectively. $\delta{ }^{13} \mathrm{C}$, straw and $\delta{ }^{13} \mathrm{C}$, without straw refer to the ${ }^{13} \mathrm{C}$ signature of the ryegrass straw and the soil/floc mixture, respectively. The soil and flocs ${ }^{13} \mathrm{C}(-26.7$ to $-15.8 \%$ ) were considered as background in the presence of highly enriched ryegrass straw (538\%). We carried out the calculation (Eq. 5) using the ${ }^{13} \mathrm{C}$ signature of soil or flocs and the results did not vary $(\mathrm{CV}<1 \%)$. Thus, we treated the soil and floc mixture as one C pool, named "soil-floc" pool (with the measured $\delta{ }^{13} \mathrm{C}$ value of $-16.1 \%$ ). By using this approach, we also acknowledge that $\mathrm{CO}_{2}$ derived from the soil or the flocs in the ryegrass straw addition 
treatments could not be differentiated. The PE of the ryegrass addition on $\mathrm{C}$ mineralization of soil-floc pool was estimated to be the difference between the $\mathrm{C}-\mathrm{CO}_{2}$ derived from soil-floc pool in the ryegrass treatments and the total $\mathrm{C}-\mathrm{CO}_{2}$ production in the treatments without ryegrass. The large difference in the ${ }^{13} \mathrm{C}$ enrichment between the soil-floc and ryegrass was sufficient to reliably estimate the change in the contribution of ryegrass to total $\mathrm{CO}_{2}$ production.

The fraction of extracted DOC derived from flocs or soil/floc mixture in the treatments without ryegrass or with ryegrass was calculated using the same approach for $\mathrm{CO}_{2}$ fraction calculation (see above).

\section{Statistical analyses}

A two-way Analysis of variance (ANOVA) was performed using PROC Mixed procedures in SAS (SAS 9.3, SAS Institute Inc., Cary, N.C., USA). Differences were considered significant at $P<0.05$, with a separation of mean values by a least significant difference (LSD) test. In the treatments without or with ryegrass residue, clay type and Fe level were treated as fixed factors, and replicate as a random factor, to test their effect on cumulative $\mathrm{CO}_{2}$ production, PE, and DOC content at the end of the incubation.

\section{Results}

Properties of flocs

Regardless of Fe levels (none, low, or high), the maximum DOC sorption capacity of montmorillonite flocs was larger than that of kaolinite flocs (Table 2).
Coating clays with Fe enhanced DOC sorption capacity of both montmorillonite and kaolinite clays, with the high Fe-treated clays adsorbing more DOC than the low Fe-treated clays. The CEC decreased in the flocs containing higher Fe content. The floc made without clay adsorbed higher DOC compared to the flocs made with clays (Table 2).

Cumulative $\mathrm{CO}_{2}$ production and source partitioning

In all treatments, cumulative $\mathrm{CO}_{2}$ production increased gradually throughout the entire incubation (Fig. 1). In treatments without ryegrass, total $\mathrm{CO}_{2}$ production in DOC treatments were significantly higher than other floc treatments (Table 3). More $\mathrm{CO}_{2}$ was produced in treatments containing flocs made with kaolinite alone or combined with low level of $\mathrm{Fe}$ than comparable treatments with montmorillonite. In treatments with ryegrass, the total $\mathrm{CO}_{2}$ production in the DOC-only treatment was similar to the treatments of $\mathrm{K}-\mathrm{OC}$ and $\mathrm{Fe}_{\mathrm{low}}-\mathrm{K}-\mathrm{OC}$ significantly higher than other floc treatments. In floc treatments with no or low $\mathrm{Fe}$, higher $\mathrm{CO}_{2}$ production was found in kaolinite flocs than montmorillonite flocs (Table 3).

The fractional contributions of floc and native SOC to total $\mathrm{CO}_{2}$ production were determined for all the treatments without ryegrass (Fig. 2A). In all the treatments of flocs made without Fe, floc was the dominant source of $\mathrm{CO}_{2}$ produced while native SOC contributed significantly to the total $\mathrm{CO}_{2}$ production in floc treatments made with $\mathrm{Fe}$ regardless of its level. The total $\mathrm{CO}_{2}$ production derived from floc in all treatments was significantly lower than the $\mathrm{CO}_{2}$ produced from DOC decomposition in the DOC-only

Table 2 Characteristics of flocs

\begin{tabular}{llllllll}
\hline Treatments & Fe-OC & \multicolumn{2}{l}{ Montmorillonite kaolinite } & & \\
\cline { 2 - 7 } & & $\mathrm{M}-\mathrm{OC}$ & $\mathrm{Fe}_{\text {low }}-\mathrm{M}-\mathrm{OC}$ & $\mathrm{Fe}_{\text {high }}-\mathrm{M}-\mathrm{OC}$ & $\mathrm{K}-\mathrm{OC}$ & $\mathrm{Fe}_{\text {low }}-\mathrm{K}-\mathrm{OC}$ & $\mathrm{Fe}_{\text {high }}-\mathrm{K}-\mathrm{OC}$ \\
\hline $\mathrm{CEC}^{\mathrm{b}}\left(\mathrm{cmol} \mathrm{kg}^{-1}\right)$ & - & 84.4 & 49.0 & 1.9 & 2.0 & 1.3 & - \\
$\mathrm{Fe}^{\mathrm{c}}\left(\mathrm{mg} \mathrm{g}^{-1}\right)$ & 9.0 & - & 11.4 & 219.0 & - & 5.4 & 199.0 \\
Sorbed C $\left(\mathrm{mg} \mathrm{C} \mathrm{g}^{-1}\right)$ & 340.0 & 4.0 & 9.1 & 26.0 & 2.4 & 6.3 & 22.0 \\
\hline
\end{tabular}

${ }^{\mathrm{a}} \mathrm{Fe}$ coagulated with dissolved organic carbon

${ }^{\mathrm{b}}$ Cation exchange capacity

${ }^{\mathrm{c}}$ Carbon content of flocs 


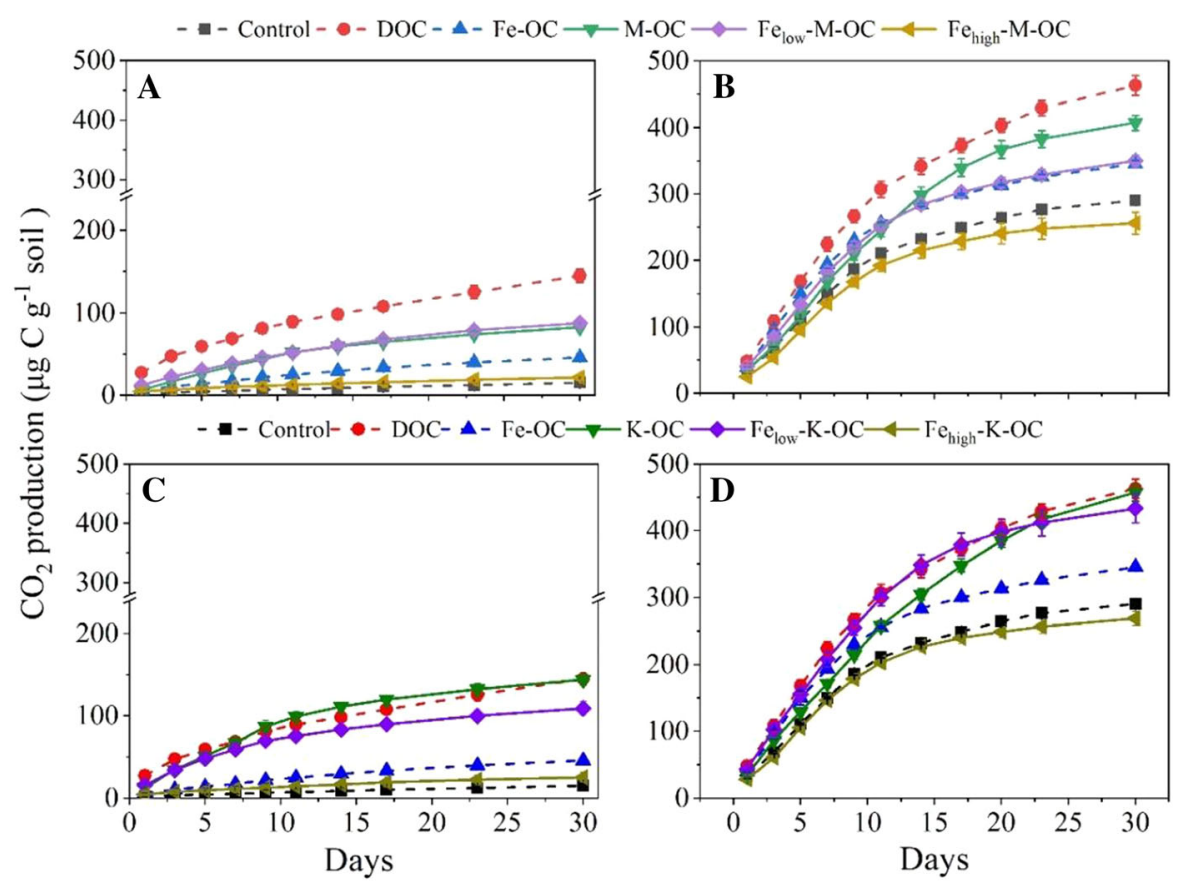

Fig. 1 Cumulative $\mathrm{CO}_{2}$ production from different floc treatments incubated without (A and $\left.\mathbf{C}\right)$ and with ryegrass $(\mathbf{B}$ and $\mathbf{D})$. Error bars represent standard error of the means $(n=4)$

Table 3 Cumulative $\mathrm{CO}_{2}$ production $\left(\mathrm{CO}_{2}-\mathrm{C} \mathrm{ug} \mathrm{g}^{-1}\right)$ during incubation period and extracted DOC $\left(\mu \mathrm{g} \mathrm{g}^{-1}\right)$ at the end of incubation from different treatments without and with ryegrass $(n=4)$

\begin{tabular}{|c|c|c|c|c|c|}
\hline \multirow[t]{2}{*}{ Treatments } & \multirow[t]{2}{*}{ Added floc $\mathrm{mg} \mathrm{C}^{-1}$} & \multicolumn{2}{|l|}{ Without ryegrass } & \multicolumn{2}{|l|}{ With ryegrass } \\
\hline & & $\mathrm{CO}_{2}$ production & DOC content & $\mathrm{CO}_{2}$ production & DOC content \\
\hline Control & 0 & $19.6(1.2) \mathrm{f}$ & $7.35(0.5) \mathrm{c}$ & $302.7(10.0) \mathrm{e}$ & $15.03(0.6) \mathrm{f}$ \\
\hline DOC & 0.2 & $148.2(0.6) \mathrm{a}$ & $96.71(12.0) \mathrm{a}$ & $463.2(13.5) \mathrm{a}$ & $111.61(2.5) \mathrm{a}$ \\
\hline $\mathrm{Fe}-\mathrm{OC}$ & 0.2 & $50.7(2.4) \mathrm{e}$ & $46.13(0.9) \mathrm{b}$ & $344.7(14.4) \mathrm{d}$ & $57.13(2.7) \mathrm{b}$ \\
\hline $\mathrm{M}-\mathrm{OC}$ & 0.2 & $87.9(1.4) \mathrm{d}$ & $17.41(0.7) \mathrm{c}$ & $407.2(11.3) \mathrm{c}$ & $31.37(0.5) \mathrm{c}$ \\
\hline $\mathrm{Fe}_{\text {low }}-\mathrm{M}-\mathrm{OC}$ & 0.2 & $82.6(1.5) \mathrm{d}$ & $27.10(0.9) \mathrm{c}$ & $350.9(7.0) \mathrm{d}$ & $39.94(1.0) \mathrm{c}$ \\
\hline $\mathrm{Fe}_{\text {high }}-\mathrm{M}-\mathrm{OC}$ & 0.2 & $25.2(2.5) \mathrm{f}$ & $13.92(0.7) \mathrm{c}$ & $256.1(17.1) \mathrm{f}$ & $17.07(0.7) \mathrm{f}$ \\
\hline $\mathrm{K}-\mathrm{OC}$ & 0.2 & $129.7(1.8) \mathrm{b}$ & $15.38(1.6) \mathrm{c}$ & $457.3(7.9) \mathrm{ab}$ & $14.97(1.2) \mathrm{f}$ \\
\hline $\mathrm{Fe}_{\text {low }}-\mathrm{K}-\mathrm{OC}$ & 0.2 & $106.6(3.8) \mathrm{c}$ & $24.38(0.7) \mathrm{c}$ & $433.2(8.2) b c$ & $25.92(1.2) \mathrm{e}$ \\
\hline $\mathrm{Fe}_{\text {high }}-\mathrm{K}-\mathrm{OC}$ & 0.2 & $28.5(2.6) \mathrm{f}$ & $17.32(1.0) \mathrm{c}$ & $268.9(10.7) \mathrm{f}$ & $23.31(1.2) \mathrm{e}$ \\
\hline
\end{tabular}

The letters represent the differences in $\mathrm{CO}_{2}$ production or DOC among different floc treatments without or with ryegrass addition

treatment. At the end of the incubation, $45.4 \%$ of DOC was mineralized in the DOC-only treatment while $4.0-30.4 \%$ of floc-C was mineralized in floc treatments. The floc-derived $\mathrm{CO}_{2}$ production was $1.2-2.3$ times higher in the treatments of flocs made with kaolinite than that in the treatments with montmorillonite (Fig. 3A). Within the same clay treatment, $\mathrm{CO}_{2}$ produced from floc decomposition decreased as the Fe level increased. Compared with the control (soil only), the addition of flocs or DOC significantly promoted $\mathrm{CO}_{2}$ produced from native SOC, with higher SOCderived $\mathrm{CO}_{2}$ production found in the flocs made with lower level of $\mathrm{Fe}$. The type of clay minerals in the flocs made with $\mathrm{Fe}$ did not significantly impact the $\mathrm{CO}_{2}$ 


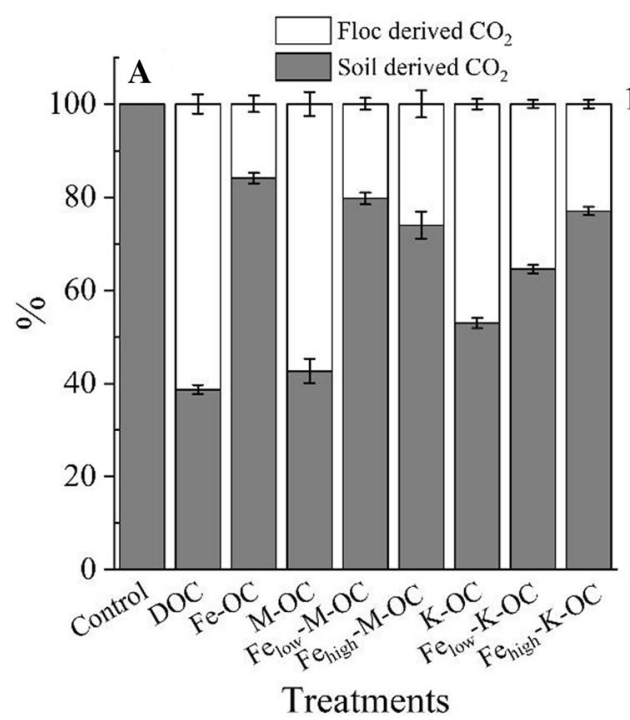

Fig. 2 Fraction of the $\mathrm{CO}_{2}$ production from floc and native soil $\mathrm{C}$ pools in the treatments without ryegrass (A) and fraction of the $\mathrm{CO}_{2}$ productions from ryegrass and floc-soil pools in the

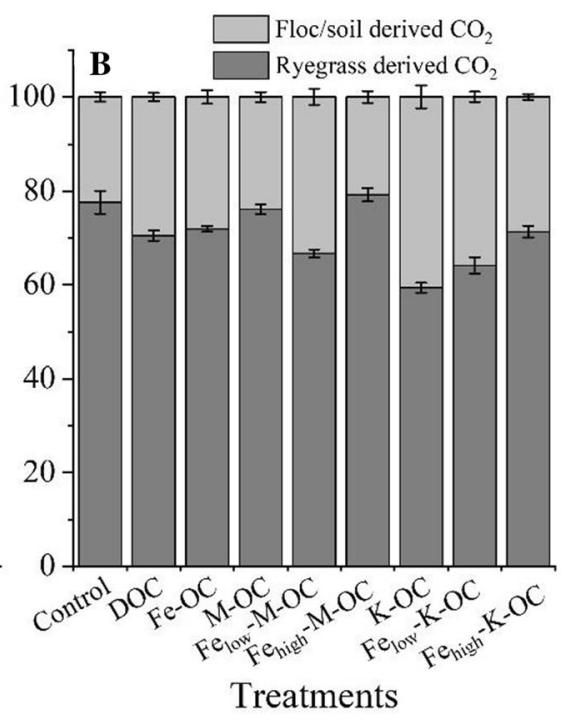

treatments with ryegrass $(\mathbf{B})$. Error bars represent standard error of the means $(n=4)$

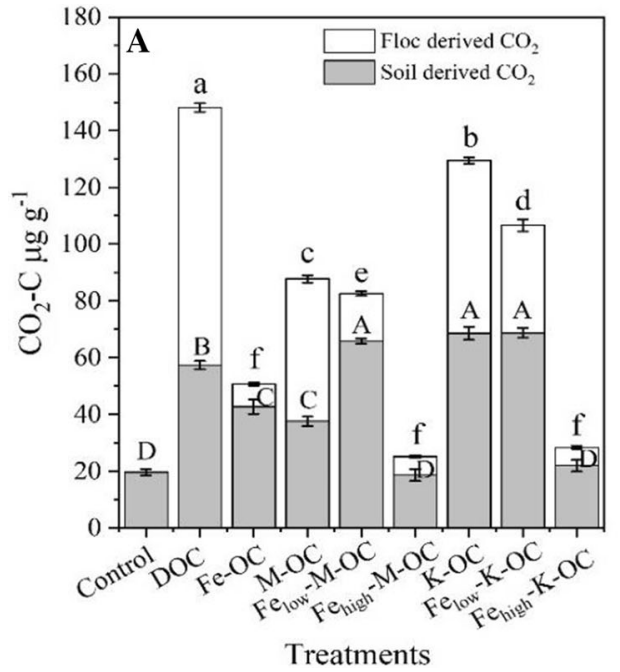

Fig. 3 Quantification of the cumulative $\mathrm{CO}_{2}$ production from floc and native soil $\mathrm{C}$ pools in the treatments without ryegrass (A) and from ryegrass and soil/floc $\mathrm{C}$ pools in the treatments with ryegrass $(\mathbf{B})$. The uppercase letters show significant differences in $\mathrm{CO}_{2}$ derived from soil or ryegrass at $P<0.05$

produced from native SOC. In the treatments of flocs made without $\mathrm{Fe}$, higher $\mathrm{SOC}$-derived $\mathrm{CO}_{2}$ production was found in kaolinite compared to montmorillonite treatments (Fig. 3A).

The fractional contributions of soil-floc mixture and ryegrass to total $\mathrm{CO}_{2}$ production were determined for all the treatments with ryegrass (Fig. 2B). As

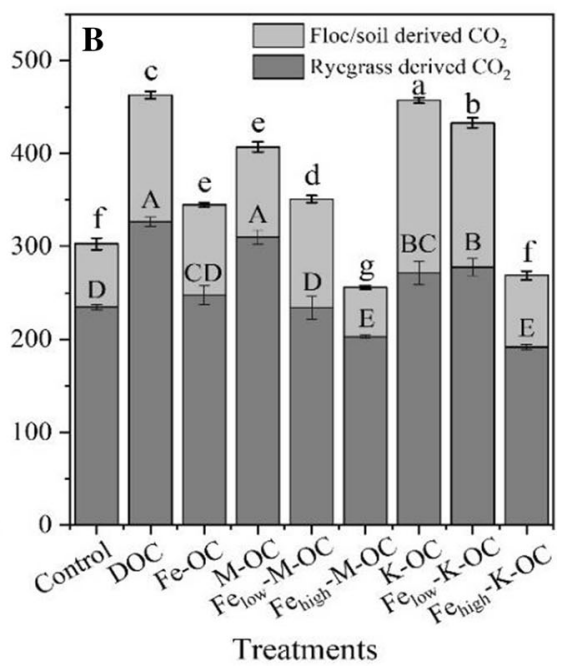

among different floc treatments without or with ryegrass. The lowercase letters show significant differences in $\mathrm{CO}_{2}$ derived from floc or soil/floc mixture at $P<0.05$ among different floc treatments without or with ryegrass. Error bars represent standard error of the means $(n=4)$

expected, ryegrass-derived $\mathrm{CO}_{2}$ production dominated total $\mathrm{CO}_{2}$ production in all treatments, ranging from 59 to $76 \%$ (Fig. 3B). In all treatments, $45-78 \%$ of ryegrass was mineralized by the end of the incubation, with the highest rate found in the DOC-only treatment. The total $\mathrm{CO}_{2}$ produced from ryegrass treatments was significantly increased by flocs made without $\mathrm{Fe}$. 
However, regardless of clay mineralogy, the flocs made with high $\mathrm{Fe}$ significantly inhibited ryegrass $\mathrm{C}$ decomposition by $14-19 \%$ while no impact of $\mathrm{Fe}-\mathrm{OC}$ floc on ryegrass decomposition was found. The total $\mathrm{CO}_{2}$ produced from the soil-floc mixture $\mathrm{C}$ pool varied significantly among floc treatments, with higher soilfloc mixture-derived $\mathrm{CO}_{2}$ production found in kaolinite compared to montmorillonite floc treatments.

Dissolved organic carbon and source partitioning

At the end of the incubation, the fractional contributions of the extracted DOC sources were determined for all treatments (Fig. 4). In the treatments without ryegrass, the floc-derived DOC changed significantly among treatments. For example, the floc-derived DOC was $85-420 \%$ higher in the Fe-OC floc treatment compared to other treatments. No significant difference in soil-derived DOC was found among all treatments except DOC-only treatment, which had higher soil-derived DOC than control and other floc treatments. Unexpectedly, the addition of ryegrass increased the total extracted DOC was only found in treatments of flocs made with montmorillonite or floc made without clay (Table 3 ). In ryegrass treatments, 44-95\% of the extracted DOC was derived from soilfloc mixture instead of ryegrass (Fig. 4). However, the

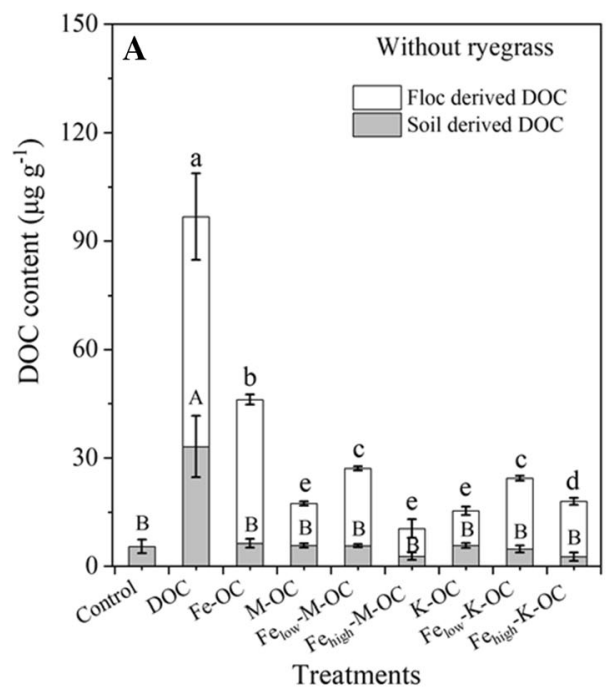

Fig. 4 Extracted DOC at the end of the incubation without (A) or with ryegrass (B). Floc material or unflocced DOC was added to the soil medium at a rate of $0.2 \mathrm{mg} \mathrm{C} \mathrm{g}^{-1}$. The uppercase letters show significant difference in DOC derived from soil or ryegrass at $P<0.05$ among different floc addition of ryegrass promoted DOC released from soil-floc mixture compared with non-ryegrass treatments.

\section{Priming effect}

The clay mineralogy and $\mathrm{Fe}$ level in flocs had a significant impact on the PE of flocs on native SOC in treatments without ryegrass (Table 4). Regardless of $\mathrm{Fe}$ level, the flocs made with kaolinite primed 2.9-31.1 $\mu \mathrm{g} \mathrm{C} \mathrm{g}^{-1}$ more $\mathrm{CO}_{2}$ from SOC than the montmorillonite flocs (Table 5). Regardless of clay mineralogy, the flocs made with low Fe significantly primed 46.8-49.2 $\mu \mathrm{g} \mathrm{C} \mathrm{g}^{-1}$ more $\mathrm{CO}_{2}$ from SOC than the high $\mathrm{Fe}$ flocs. The primed SOC-derived $\mathrm{CO}_{2}$ production in floc treatments made with $\mathrm{Fe}$ only or clay only were $11.3-19.7 \mu \mathrm{g} \mathrm{C} \mathrm{g}^{-1}$ less than in the DOC-only treatment. At the end of the incubation, a negative PE on SOC-derived DOC was found in all floc treatments while the DOC only significantly primed DOC released from SOC (Table 5).

The addition of ryegrass stimulated $3-34 \%$ more $\mathrm{CO}_{2}$ production from soil-floc mixtures compared to treatments without ryegrass, while in the DOC-only treatment, less soil-floc-derived $\mathrm{CO}_{2}$ production was observed in ryegrass treatments compared with nonryegrass treatments (Fig. 3A, B; Table 5). In treatment

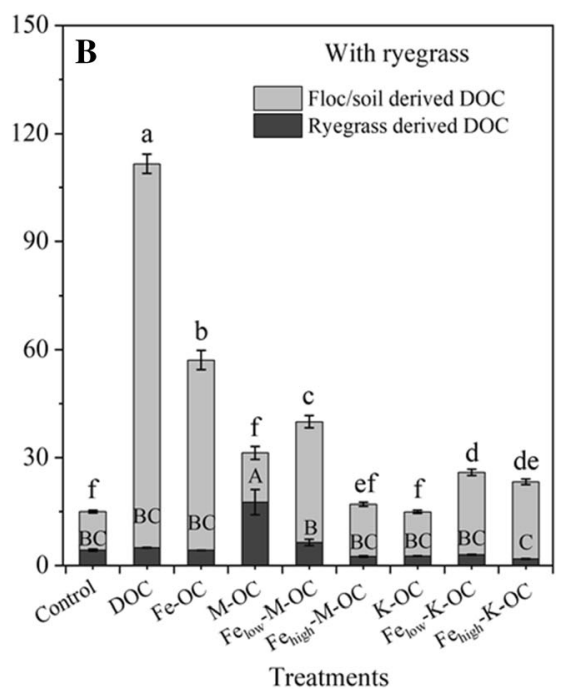

treatments without or with ryegrass. The lowercase letters show significant difference in DOC derived from floc or soil/floc mixture at $P<0.05$ among different floc treatments without or with ryegrass. Means $(n=4)$ and standard errors are shown 
Table 4 Results of analysis of variance on the effect of clay mineralogy and $\mathrm{Fe}$ level on cumulative $\mathrm{CO}_{2}$ production, extracted DOC and priming effect in the treatments without and with ryegrass over 30 days incubation

\begin{tabular}{|c|c|c|c|c|c|c|}
\hline & & Variances & df & Mean square & $F$ & $P$ \\
\hline \multirow[t]{6}{*}{ Without ryegrass } & \multirow[t]{3}{*}{$\mathrm{CO}_{2}$ production } & Clay & 2 & 1640.1 & 88.9 & $<0.001$ \\
\hline & & $\mathrm{Fe}$ & 2 & $18,226.2$ & 987.7 & $<0.001$ \\
\hline & & Clay $\times \mathrm{Fe}$ & 3 & 7912.8 & 428.8 & $<0.001$ \\
\hline & \multirow[t]{3}{*}{$\mathrm{PE}$} & Clay & 2 & 5290.5 & 153.8 & $<0.001$ \\
\hline & & $\mathrm{Fe}$ & 2 & $10,202.3$ & 296.6 & $<0.001$ \\
\hline & & Clay $\times \mathrm{Fe}$ & 3 & 1484.1 & 43.1 & $<0.001$ \\
\hline \multirow[t]{6}{*}{ With ryegrass } & \multirow[t]{3}{*}{$\mathrm{CO}_{2}$ production } & Clay & 2 & 1904.2 & 7.0 & 0.003 \\
\hline & & $\mathrm{Fe}$ & 2 & $15,327.1$ & 56.6 & $<0.001$ \\
\hline & & Clay $\times \mathrm{Fe}$ & 3 & 7893.2 & 29.2 & $<0.001$ \\
\hline & \multirow[t]{3}{*}{$\mathrm{PE}$} & Clay & 2 & 2631.2 & 22.4 & $<0.001$ \\
\hline & & $\mathrm{Fe}$ & 2 & 1005.2 & 8.6 & $<0.001$ \\
\hline & & Clay $\times \mathrm{Fe}$ & 3 & 2159.6 & 18.4 & $<0.001$ \\
\hline
\end{tabular}

Table 5 Priming effect (PE) of flocs and ryegrass residue on the $\mathrm{C}$ mineralization (or extracted DOC) of native soil or soil/floc mixture

\begin{tabular}{|c|c|c|c|c|}
\hline \multirow[t]{2}{*}{ Treatment } & \multicolumn{2}{|c|}{ Without ryegrass $\mathrm{PE}$ of $\mathrm{SOC}$} & \multicolumn{2}{|c|}{ With ryegrass $\mathrm{PE}$ of soil/floc mixture } \\
\hline & $\mathrm{CO}_{2}-\mathrm{C} \mu \mathrm{g} \mathrm{g}^{-1}$ & DOC $\mu \mathrm{g} \mathrm{g}^{-1}$ & $\mathrm{CO}_{2}-\mathrm{C} \mu \mathrm{g} \mathrm{g}^{-1}$ & DOC $\mu \mathrm{g} \mathrm{g}^{-1}$ \\
\hline Control & - & - & 48.1(7.5) ab & $3.6(0.6) \mathrm{a}$ \\
\hline DOC & $37.67(1.5) \mathrm{b}$ & $33.4(11.0) \mathrm{a}$ & $-11.5(3.5) \mathrm{e}$ & $-106.2(21.3) b$ \\
\hline $\mathrm{Fe}-\mathrm{OC}$ & $23.0(2.5) \mathrm{c}$ & $-0.4(0.8) b$ & $46.1(1.8) \mathrm{ab}$ & $7.0(2.8) \mathrm{a}$ \\
\hline $\mathrm{M}-\mathrm{OC}$ & $17.9(1.6) \mathrm{d}$ & $-1.6(0.9) b$ & $9.4(5.5) \mathrm{d}$ & $-3.7(2.3) \mathrm{a}$ \\
\hline $\mathrm{Fe}_{\text {low }}-\mathrm{M}-\mathrm{OC}$ & $46.2(0.9) \mathrm{a}$ & $-3.4(1.6) b$ & $34.1(4.3) \mathrm{bc}$ & $5.9(2.5) \mathrm{a}$ \\
\hline $\mathrm{Fe}_{\text {high }}-\mathrm{M}-\mathrm{OC}$ & $-2.8(0.8) \mathrm{f}$ & $-4.7(1.1) b$ & $28.1(3.8) \mathrm{c}$ & $0.5(1.0) \mathrm{a}$ \\
\hline $\mathrm{K}-\mathrm{OC}$ & $49.0(2.3) \mathrm{a}$ & $-1.0(0.8) b$ & $56.2(2.1) \mathrm{a}$ & $-3.1(1.6) \mathrm{a}$ \\
\hline $\mathrm{Fe}_{\mathrm{low}}-\mathrm{K}-\mathrm{OC}$ & $49.1(1.8) \mathrm{a}$ & $-2.5(0.8) b$ & $48.7(8.5) \mathrm{ab}$ & $-1.5(1.2) \mathrm{a}$ \\
\hline $\mathrm{Fe}_{\mathrm{high}}-\mathrm{K}-\mathrm{OC}$ & $2.3(2.1) \mathrm{f}$ & $-4.7(0.6) b$ & $48.6(7.3) \mathrm{ab}$ & $4.1(0.6) \mathrm{a}$ \\
\hline
\end{tabular}

$\mathrm{PE}$ was calculated as the difference in $\mathrm{CO}_{2}$ production derived from soil or soil-floc $\mathrm{C}$ pool between the treatments and control. Different letters show significant differences $(P<0.05)$ among different floc treatments without or with ryegrass addition

without flocs (control: soil only), the addition of ryegrass residue primed $\mathrm{SOC}$-derived $\mathrm{CO}_{2}$ production by $48 \mu \mathrm{g} \mathrm{C} \mathrm{g}^{-1}$. Interestingly, the ryegrass primed soil-floc-derived $\mathrm{CO}_{2}$ in floc treatments was significantly lower than or not different from the ryegrass primed SOC-derived $\mathrm{CO}_{2}$ (Table 5).

\section{Discussion}

The interaction of clay and DOC plays a key role in the stabilization of SOC, which influences its potential for C sequestration (Mikutta and Mikutta 2006; Saidy et al. 2015). The properties of clays significantly affect the amount of DOC that can be adsorbed. Pedogenic $\mathrm{Fe}$ oxides actively interact with DOC and play a pivotal role in the capacity of soil to adsorb DOC (Kahle et al. 2004). In this study, flocs made by adsorbing DOC to montmorillonite contained relatively more $\mathrm{C}$ than those with kaolinite (Table 2). Previous studies attribute the higher CEC and SSA of montmorillonite as factors affecting DOC adsorption (Saidy et al. 2013). The role of cation bridging, where $\mathrm{Fe}$ is bound to both clay and DOC was summarized by Stevenson (1994). In our treatments, high Fe-treated clays were found to adsorb more DOC than low Fetreated clays. A positive correlation was found between $\mathrm{Fe}$ content and the amount of $\mathrm{C}$ in clay-Fe- 
OC flocs (Table 2). The floc made with $\mathrm{Fe}$ and DOC without clay contained the highest amount of $\mathrm{C}$ among all the floc treatments (Table 2). The high capacity of DOC to sorb to actively forming Fe (III) precipitated (co-precipitation) has been shown to remove DOC from wetlands and water streams in situ (Ye et al. 2015; Zou et al. 2018).

Adsorbing DOC to clay and/or Fe decreased its mineralization rate by up to $85 \%$ compared to the DOC alone (Table 3); the extent to which mineralization rate was reduced depends on clay mineralogy and Fe levels (Saidy et al. 2012). These results are in line with previous studies, which showed that mineralization of OC adsorbed to clay minerals was reduced by 27-43\% compared with free OC (Chenu and Plante 2006; Saidy et al. 2015). Generally, simple compounds such as glucose and citrate can be easily mineralized even after they adsorb to clay minerals (Jones and Edwards 1998). The reduction in mineralization rate of adsorbed $\mathrm{C}$ over extended periods is most likely due to the reduced mineralization rate of complex compounds (e.g., lignin and polyphenols) that have been adsorbed. In this study, significantly more $\mathrm{C}$ was mineralized from flocs made with kaolinite than montmorillonite when no $\mathrm{Fe}$ or low $\mathrm{Fe}$ was included in the flocs; however, in flocs made with high $\mathrm{Fe}$, the difference in $\mathrm{C}$ mineralization rate between the two types of clay mineralogy disappeared (Fig. 3). These results indicate that the surface of clay mineralogy and Fe levels play a positive interactive role in controlling $\mathrm{C}$ stability of flocs. A similar result was also reported by Saidy et al. (2015), who found that microbial degradation differences between OC adsorbed to kaolinite and smectite depended on the presence of $\mathrm{Fe}$ in flocs. The mineralization rate of the adsorbed OC decreased as the Fe content in flocs increased (Fig. 3).

In flocs made with clays, $\mathrm{Fe}$ (III) adheres to the clay surface or incorporates into the clay lattice without influencing floc adsorptive properties (Carroll 1958; Bhattacharyya and Sen Gupta 2008). In instances where $\mathrm{Fe}$ is present as a (hydr)oxide coating, the surface (and adsorption) properties of the floc change. In this study, when the highest amount of $\mathrm{Fe}$ was present in flocs, no significant difference in $\mathrm{C}$ mineralization was observed between kaolinite and montmorillonite flocs, indicating that mineralization of $\mathrm{C}$ in these flocs was controlled predominantly by $\mathrm{Fe}$ rather than clay mineralogy. Therefore, while clay mineralogy and $\mathrm{Fe}$ both affect $\mathrm{C}$ mineralization, the relative amount of each must be considered in defining C stabilization potential.

In general, compared with 1:1 clays (i.e. kaolinite), 2:1 clays (i.e. montmorillonite) have larger CEC, which facilitates greater adsorption of positively charged metals such as ferric ions (Greenland 1971). The net charge on the montmorillonite surface remains negative if a limited amount of $\mathrm{Fe}$ is adsorbed. The sorption of DOC to Fe-treated montmorillonite is expected to occur via non-coulombic mechanisms or cation bridging. For kaolinite, a net positive charge occurs when Fe-adsorbs to the surface and allows for absorbing negatively-charged DOC via coulombic mechanisms such as ligand exchange (Zhuang and $\mathrm{Yu}$ 2002; Saidy et al. 2013). Consequently, the stability of $\mathrm{C}$ adsorbed onto these two types of clays likely differs. This is reflected in our results showing that the PE of flocs made with the two different clays on SOC decomposition varied (Table 5). In this study, the floc made with kaolinite promoted SOC decomposition compared to montmorillonite. However, when Fe was present in flocs, the floc-primed SOC decomposition was decreased as the Fe content increased in flocs, regardless of clay mineralogy (Table 5). These results indicate that the interaction between $\mathrm{Fe}$ and clay can enhance the resistance of OC in flocs and in SOC to microbial decomposition.

As expected, the addition of ryegrass increased total $\mathrm{CO}_{2}$ production from all treatments, with higher $\mathrm{CO}_{2}$ production found in kaolinite treatments than montmorillonite treatments (Table 3). Interestingly, the decomposition of ryegrass residue was inhibited by flocs made with high Fe combined with clay. This is probably due to the inhibitory effect of large amounts of Fe on microbial activity (Jones and Edwards 1998). However, no impact of $\mathrm{Fe}-\mathrm{OC}$ floc on the ryegrass was found while significant higher ryegrass decomposition rate occurred in the DOC-only treatment (Fig. 3B). These results indicate that the presence of $\mathrm{Fe}$ in flocs can protect $\mathrm{OC}$ from decomposition and can therefore slow down the microbial $\mathrm{C}$ turnover process.

Over the course of the incubation with ryegrass residue, the majority of total $\mathrm{CO}_{2}$ was derived from ryegrass but the DOC extracted at the end of the incubation was mainly derived from the soil-floc mixture (Fig. 4). This result was in line with Hagedorn et al. (2004), who reported that an external C input was preferentially respired as $\mathrm{CO}_{2}$ but the majority of DOC 
originated from native SOC. Toosi et al. (2012) also reported that only $8-14.5 \%$ of the total extractable DOC was derived from added ryegrass residue. In their study, the addition of ryegrass residue promoted two times more $\mathrm{CO}_{2}$ derived from SOC compared with the control (soil only), an example of positive PE. In our study, a similar positive PE was also observed for all floc treatments except for the DOC-only treatment (Table 5), where a negative PE was found. Unexpectedly, the PE of ryegrass on soilfloc-derived $\mathrm{CO}_{2}$ or DOC in floc treatments was significantly lower than or not different from the ryegrass primed SOC-derived $\mathrm{CO}_{2}$ or DOC (Table 5), indicating that flocs can decrease the $\mathrm{PE}$ of ryegrass on native SOC decomposition and therefore increase the potential of soil $\mathrm{C}$ sequestration.

\section{Conclusion}

In this study, flocs made with montmorillonite absorbed and stabilized more DOC than kaolinite regardless of Fe content in the flocs. The stability of the adsorbed DOC in flocs was also controlled by the nature of the interaction between clay mineralogy and Fe. For flocs made with high Fe content, the stability of adsorbed DOC was not affected by clay mineralogy, showing that higher amounts of $\mathrm{Fe}$ overcome the mineralogical characteristics of clay type in adsorbing DOC. The inclusion of synthetic flocs promoted SOC decomposition with kaolinite derived flocs having a higher PE than montmorillonite flocs. Higher primed SOC-derived $\mathrm{CO}_{2}$ was also found in the floc treatments with low or no Fe compared to those with high $\mathrm{Fe}$ content. The addition of ryegrass residue accelerated $\mathrm{C}$ mineralization from the soil-floc mixture. On the other hand, flocs significantly decreased the PE of ryegrass on SOC decomposition. The application of high-Fe clay flocs also inhibited the decomposition of ryegrass residue. Considering cumulative $\mathrm{C}$ mineralization and extractable DOC remaining in the soil mixture, the flocs made with montmorillonite and/or high Fe content offered better protection of adsorbed $\mathrm{C}$, SOC and recent plant $\mathrm{C}$ inputs against microbial decomposition compared to flocs made with kaolinite and/or low Fe. Overall, clay mineralogy and Fe levels in flocs had a significant effect on $\mathrm{C}$ mineralization of clay- $\mathrm{Fe}-\mathrm{C}$ products and soil $\mathrm{C}$ stability and provides insights into the role of $\mathrm{Fe}$ in affecting PE.
Acknowledgements The study was supported by the J.G. Boswell Endowed Chair in Soil Science and Chinese Scholarship Council.

Open Access This article is licensed under a Creative Commons Attribution 4.0 International License, which permits use, sharing, adaptation, distribution and reproduction in any medium or format, as long as you give appropriate credit to the original author(s) and the source, provide a link to the Creative Commons licence, and indicate if changes were made. The images or other third party material in this article are included in the article's Creative Commons licence, unless indicated otherwise in a credit line to the material. If material is not included in the article's Creative Commons licence and your intended use is not permitted by statutory regulation or exceeds the permitted use, you will need to obtain permission directly from the copyright holder. To view a copy of this licence, visit http://creativecommons.org/licenses/by/4.0/.

Data availability The datasets are available from the corresponding author on reasonable request.

\section{References}

Balcke GU, Kulikova NA, Hesse S, Kopinke FD, Perminova IV, Frimmel FH (2002) Adsorption of humic substances onto kaolinclayrelatedtotheirstructuralfeatures.SoilSciSocAmJ 66:1805-1812.https://doi.org/10.2136/sssaj2002.1805

Bertrand I, Chabbert B, Kurek B, Recous S (2006) Can the biochemical features and histology of wheat residues explain their decomposition in soil? Plant Soil 281:291-307. https://doi.org/10.1007/s11104-005-4628-7

Bhattacharyya KG, Sen Gupta S (2008) Kaolinite and montmorillonite as adsorbents for $\mathrm{Fe}(\mathrm{III}), \mathrm{Co}(\mathrm{II})$ and $\mathrm{Ni}(\mathrm{II})$ in aqueous medium. Appl Clay Sci 41:1-9. https://doi.org/10. 1016/j.clay.2007.09.005

Bird JA, van Kessel C, Horwath WR (2003) Stabilization of $\mathrm{C}$-13-carbon and immobilization of N-15-nitrogen from rice straw in humic fractions. Soil Sci Soc Am J 67:806-816. https://doi.org/10.2136/sssaj2003.0806

Carroll D (1958) Role of clay minerals in the transportation of iron. Geochim Cosmochim Acta 14:1. https://doi.org/10. 1016/0016-7037(58)90090-5

Chenu C, Plante AF (2006) Clay-sized organo-mineral complexes in a cultivation chronosequence: revisiting the concept of the "primary organo-mineral complex." Eur J Soil Sci 57:596-607. https://doi.org/10.1111/j.1365-2389. 2006.00834.x

Eusterhues K, Rumpel C, Kogel-Knabner I (2005) Organomineral associations in sandy acid forest soils: importance of specific surface area, iron oxides and micropores. Eur J Soil Sci 56:753-763. https://doi.org/10.1111/j.1365-2389. 2005.00710.x

Eusterhues K et al (2008) Characterization of ferrihydrite-soil organic matter coprecipitates by X-ray diffraction and 
mossbauer spectroscopy. Environ Sci Technol 42:7891-7897. https://doi.org/10.1021/es800881w

Feng XJ, Simpson AJ, Simpson MJ (2005) Chemical and mineralogical controls on humic acid sorption to clay mineral surfaces. Org Geochem 36:1553-1566. https://doi.org/10. 1016/j.orggeochem.2005.06.008

Greenland DJ (1971) Interactions between humic and fulvic acids and clays. Soil Sci 111:34. https://doi.org/10.1097/ 00010694-197101000-00004

Hagedorn F, Saurer M, Blaser P (2004) A C-13 tracer study to identify the origin of dissolved organic carbon in forested mineral soils. Eur J Soil Sci 55:91-100. https://doi.org/10. 1046/j.1365-2389.2003.00578.x

Han L, Sun K, Jin J, Xing B (2016) Some concepts of soil organic carbon characteristics and mineral interaction from a review of literature. Soil Biol Biochem 94:107-121. https://doi.org/10.1016/j.soilbio.2015.11.023

Henneberry YK, Kraus TEC, Nico PS, Horwath WR (2012) Structuralstabilityofcoprecipitatednaturalorganicmatterandferric iron under reducing conditions. Org Geochem 48:81-89. https://doi.org/10.1016/j.orggeochem.2012.04.005

Jones DL, Edwards AC (1998) Influence of sorption on the biological utilization of two simple carbon substrates. Soil Biol Biochem 30:1895-1902. https://doi.org/10.1016/ s0038-0717(98)00060-1

KahleM,KleberM,JahnR(2002)Predictingcarboncontentinillitic clayfractionsfromsurfacearea, cationexchangecapacity and dithionite-extractableiron.EurJSoilSci53:639-644.https:// doi.org/10.1046/j.1365-2389.2002.00487.x

Kahle M, Kleber M, Jahn R (2004) Retention of dissolved organic matter by phyllosilicate and soil clay fractions in relation to mineral properties. Org Geochem 35:269-276. https://doi.org/10.1016/j.orggeochem.2003.11.008

Kaiser K, Guggenberger G (2007) Sorptive stabilization of organic matter by microporous goethite: sorption into small pores vs. surface complexation. Eur J Soil Sci 58:45-59. https://doi.org/10.1111/j.1365-2389.2006.00799.x

Larsen KR (2009) Corrosion-resistant coatings incorporate metal oxide nanoparticles. Mater Perform 48:23-23

Mikutta R, Mikutta C (2006) Stabilization of organic matter at micropores $(<2 \mathrm{~nm})$ in acid forest subsoils. Soil Sci Soc Am J 70:2049-2056. https://doi.org/10.2136/sssaj2005. $0366 \mathrm{~N}$

Mikutta R, Kleber M, Torn MS, Jahn R (2006) Stabilization of soil organic matter: association with minerals or chemical recalcitrance? Biogeochemistry 77(1):25-56. https://doi. org/10.1007/s10533-005-0712-6

Mikutta R, Mikutta C, Kalbitz K, Scheel T, Kaiser K, Jahn R (2007) Biodegradation of forest floor organic matter bound to minerals via different binding mechanisms. Geochim Cosmochim Acta 71:2569-2590. https://doi.org/10.1016/j. gca.2007.03.002

Rasmussen C, Heckman K, Wieder WR, Keiluweit M, Lawrence CR, Berhe AA, Blankinship JC, Crow SE, Druhan JL, Hicks Pries CE, Marin-Spiotta E, Plante AF, Schädel C, Schimel JP, Sierra CA, Thompson A, Wagai R (2018) Beyond clay: towards an improved set of variables for predicting soil organic matter content. Biogeochemistry 137:297-306. https://doi.org/10.1007/s10533-018-0424-3

Saidy AR, Smernik RJ, Baldock JA, Kaiser K, Sanderman J, Macdonald LM (2012) Effects of clay mineralogy and hydrous iron oxides on labile organic carbon stabilisation. Geoderma 173:104-110. https://doi.org/10.1016/j. geoderma.2011.12.030

Saidy AR, Smernik RJ, Baldock JA, Kaiser K, Sanderman J (2013) The sorption of organic carbon onto differing clay minerals in the presence and absence of hydrous iron oxide. Geoderma 209:15-21. https://doi.org/10.1016/j.geoderma. 2013.05.026

Saidy AR, Smernik RJ, Baldock JA, Kaiser K, Sanderman J (2015) Microbial degradation of organic carbon sorbed to phyllosilicate clays with and without hydrous iron oxide coating. Eur J Soil Sci 66:83-94. https://doi.org/10.1111/ ejss. 12180

Six J, Conant RT, Paul EA, Paustian K (2002) Stabilization mechanisms of soil organic matter: implications for C-saturation of soils. Plant Soil 241:155-176. https://doi. org/10.1023/a:1016125726789

Sodano M, Said-Pullicino D, Fiori AF, Catoni M, Martin M, Celi L (2016) Sorption of paddy soil-derived dissolved organic matter on hydrous iron oxide-vermiculite mineral phases. Geoderma 261:169-177. https://doi.org/10.1016/j. geoderma.2015.07.014

Stevenson FJ (1994) Humus chemistry: genesis, composition, and reactions, 2nd edn. Wiley, New York

Toosi ER, Doane TA, Horwath WR (2012) Abiotic solubilization of soil organic matter, a less-seen aspect of dissolved organic matter production. Soil Biol Biochem 50:12-21. https://doi.org/10.1016/j.soilbio.2012.02.033

von Luetzow M, Koegel-Knabner I, Ekschmitt K, Matzner E, Guggenberger G, Marschner B, Flessa H (2006) Stabilization of organic matter in temperate soils: mechanisms and their relevance under different soil conditions-a review. Eur J Soil Sci 57:426-445. https://doi.org/10.1111/ j.1365-2389.2006.00809.x

Wang WJ, Dalal RC, Moody PW, Smith CJ (2003) Relationships of soil respiration to microbial biomass, substrate availability and clay content. Soil Biol Biochem 35:273-284. https://doi.org/10.1016/s0038-0717(02)00274-2

Ye R, Doane TA, Morris J, Horwath WR (2015) The effect of rice straw on the priming of soil organic matter and methane production in peat soils. Soil Biol Biochem 81:98-107. https://doi.org/10.1016/j.soilbio.2014.11.007

Zhang L, Luo L, Zhang S (2012) Integrated investigations on the adsorption mechanisms of fulvic and humic acids on three clay minerals. Colloids Surf A 406:84-90. https://doi.org/ 10.1016/j.colsurfa.2012.05.003

Zhuang J, Yu GR (2002) Effects of surface coatings on electrochemical properties and contaminant sorption of clay minerals. Chemosphere 49:619-628. https://doi.org/10. 1016/S0045-6535(02)00332-6

Zou Y, Zhang S, Huo L, Sun G, Lu X, Jiang M, Yu X (2018) Wetland saturation with introduced $\mathrm{Fe}(\mathrm{III})$ reduces total carbon emissions and promotes the sequestration of DOC. Geoderma 325:141-151. https://doi.org/10.1016/j. geoderma.2018.03.031

Publisher's Note Springer Nature remains neutral with regard to jurisdictional claims in published maps and institutional affiliations. 